\title{
"The Wild Underground Extreme of Human Rights and Ecological Activities": Czechoslovak, Czech and Slovenian Hardcore Punk Fanzine Cultures from the 1980s to the Present ${ }^{*}$
}

\author{
Jiří Almer
}

\begin{abstract}
ALMER, Jiři: "The wild underground extreme of human rights and ecological activities": Czechoslovak, Czech and Slovenian hardcore punk fanzine cultures from the 1980s to the Present.

This article compares Czechoslovak, Czech and Slovenian hardcore punk fanzine scenes from the 1980s up to the present, emphasising in particular their connections to the various anti-authoritarian movements with which they share the common idea of do-it-yourself (DIY). The comparison is embodied in the histories of above-mentioned scenes and in the context of their legacies. Fanzines are the author's main sources mainly because cultural and political activities were connected on their pages. While Czech hardcore-punk fanzine culture has persisted until today, Slovenian fanzines in fact have disappeared hand-in-hand with advancing gentrification, despite the punk scenes being remarkably strong there during the period of socialism.
\end{abstract}

Keywords: hardcore-punk, punk, fanzine, subculture, scene, activism, DIY, Czechia, Slovakia, Slovenia DOI: https://doi.org/10.31577/forhist.2020.14.1.6

$\mathrm{B}$ eing a part of a subculture is often an important form of identification for youth and can help foster greater involvement in social and political activism. Especially in the case of punk and the hardcore punk and anarcho-punk subgenres/ scenes in particular, ${ }^{1}$ we can trace the continual articulation of lifestyles and political persuasions, such as vegetarianism/veganism or even the more radical straight edge as well as their remarkable similarly oriented political activity, as contemporary autonomist or anti-authoritarian movements. ${ }^{2}$ More specifically,

\footnotetext{
* This quote comes from Czech punk chronicler Filip Fuchs (see below). FUCHS, Filip as Phill Hell. In Trhavina, 2013, No. 4. This article was created as a part of research supported by Czech Science Foundation project no. 17-09539S Budováni scény: česká a slovenská kultura fanzinů od státního socialismu k post-socialismu / Building up the Scene: Czech and Slovak Fanzine Culture from the State Socialism to Post-Socialism. Research presented here develops author's argument in a chapter from the book DANIEL, Ondřej a kol. Kultura svépomocí: ekonomické a politické rozměry v českém subkulturním prostredí pozdního státního socialismu a postsocialismu. Praha : FFUK, 2016 and a conference paper presented at konference České, slovenské a československé dějiny 20. století XII in 2018.

1 Since bands that openly propagate the ideas of anarchism are usually labelled as anarcho-punk, in this context hardcore is interpreted as a scene propagating wider social engagement and alternative lifestyles. Alastair Gordon interprets anarcho-punk as a particularly British movement that developed around the band Crass in the 1980s, whereas he connects hardcore to the United States. In this text I use the term hardcore punk because in the studied countries the hardcore and anarcho-punk scenes have nearly merged into one. GORDON, Alistair. They Can Stuff Their Punk Credentials Cause It's Them That Take the Cash. In DINES, Mike - WORLEY, Matthew (eds.) The Aesthetic of Our Anger; Anarcho-Punk, Politics and Music. Colchester : Minor Compositions, 2016, p. 246-249.
}

2 I use the term "anti-authoritarianism" as a catchall for more radical environmental, cultural, and social movements. The term also had roots in the anarchist position against Trotskyism and Maoism. 
we can speak about anti-fascist, anti-racist, anti-sexist, environmental and animal rights movement issues as well as anti-militarist and anti-globalisation activities often related to autonomous centres/squats. These trends are often interpreted as a challenge to neoliberal capitalism-based grassroots activism. Here, we can contextualise the key idea of hardcore punk - the do it yourself (DIY) ethics - that is, independence from official (commercial) sources and resistance to the commodification of cultural products. ${ }^{3}$ One crucial DIY activity is fanzine publishing, which is an independent medium that informs the scene about social activities. Fanzine culture also poses a challenge to the ethos of "professional" magazine publishing, which is based on commerce or even pro-regime discourse. According to Kirsty Five, to be a fanzine publisher means being an outsider on the one hand and a force for social change on the other. ${ }^{4}$

George McKay, an influential expert on Western anti-authoritarian activism, understands DIY practices and the ideas associated with them as constituting intuitive liberal anarchism. ${ }^{5}$ The process of establishing the above-mentioned anti-authoritarian groups in the former Eastern Bloc from late state socialism to the early post-socialist transformation is closely connected with punk and new wave subcultures, that is, the subcultures that essentially articulated DIY practice. According to one observer, the Slovenian scene, and in particular its fanzines, which were extraordinarily open and visually provocative (e.g., they contained pornographic elements), had a remarkable influence on society as a whole at a time when the adoption of capitalism was being discussed. ${ }^{6}$ Moreover, we must keep in mind that these developments were occurring as the threat of state repression still loomed large. ${ }^{7}$

Despite this obvious common repressive feature, Slovenia was probably the most liberal of the socialist countries in Europe. In contrast, Czechoslovakia was ruled by a strongly conservative socialist regime. Regardless, its direct proximity to the West may have played an important role in the cultural transfer, especially during late state socialism and the first few years of transformation. Both Slovenia and the Czech Republic (as well as Slovakia) were born out of the post-socialist breakup of larger multinational states; as a result, the subcultural scenes in these countries were able to integrate into the global community more quickly.

Did Central European subculture fanzines in the above-mentioned countries have an influence on society as a whole? How did these relations change during the diversifying social transformations and what were the visible differences between

3 TRIGGS, Teal. Scissors and Glue: Punk Fanzines and the Creation of a DIY Aesthetic. In Journal of Design History, 2006, Vol. 19, No. 1, p. 70.

4 FIFE, Kirsty. The Personal is Historical: The Ethics of Archiving Zine Subcultures. MA dissertation. University College London, Department of Information Studies, 2013, p. 20-21; Interview with Iny. In Hlasatel, 2011, No. 1, p. 51.

5 McKAY, George. DiY Culture: Notes Towards an Intro. In McKAY, George (ed.) DiY Culture: Party \& Protest in Nineties Britain. London : Verso 1998, p. 3.

6 Interview with Domen Repnik. Ljubljana, November 2016.

7 DANIEL, Ondřej. Násilím proti "novému biedermeieru": Subkultury a většinová společnost pozdního státního socialismu a postsocialismu. Praha : Pistorius \& Olšanská 2017, pp. 35, 86-87, 91-94. 
the above-mentioned countries? For my research, I mostly drew from subculture fanzines ${ }^{8}$ as sources, but also used oral history data, official documents, multimedia sources (videos) and the webpages of various cultural institutions. I do not, however, view fanzines as just sources; they also comprise a medium that expresses more complex social values. My methodology is heavily influenced by the work of Matt Grimes, who suggests primarily analysing the discursive elements of fanzines. In his opinion, the visual form of these publications and the very punk lifestyle are secondary considerations. ${ }^{9}$ Concerning the comparative goal of this study, this will be included and disputed in the two chapters dealing with the Slovenian scenes.

\section{Subcultural Theory and the Politicisation of Subcultures}

The punk subculture, its "rebellion without a cause" and its fashion comprised a major area of focus for the University of Birmingham's Centre for Contemporary Cultural Studies (CCCS). This research institute was known for unorthodox readings of Marxism and scholarship connecting subcultures with symbolical resistance against the mainstream's cultural hegemony. ${ }^{10}$ Today, however, the preferred approach is that of post-subcultural theory; the focus now tends to be on young people having fun (raves, sound systems), who are connected by the shared emotion of a collective event, which is often regarded as a new form of cultural identification. ${ }^{11}$ To better explain "subcultural" activities, scholars work with the term "subcultural scene", which is defined as a complex of (sub)cultural activities, events or products based on articulating a particular genre, which is usually, but not always, a musical one. ${ }^{12} \mathrm{~A}$ scene can be viewed as a sphere where politics and cultural activities intertwine. Scenes are usually based locally in a physical space and are organised hierarchically (following an alternative model). ${ }^{13}$

Therefore, we must avoid limiting subcultural research to fashion or employment work, and, on the contrary, we should emphasise activities, such as promoting concerts or releasing records. Sarah Thornton's key term "subcultural capital" is helpful for interpreting such activities. Not only can it be applied to the products of these activities, but it also represents a priceless value for the subcultural

8 In its original context, the term fanzine (a "fan magazine") refers to a publication produced by fans on a non-commercial basis. The truncated zine is usually used for the contemporary artzines; cutting out the fan evokes the idea that their publishers are no longer fans but artists. For more see, SPENCER, Amy. DIY: The Rise of Lo-fi Culture. New York : Marion Boyars Publishers, 2008, pp. 16-17. Compare with BESKKOVNIK, Barbara. Od fanzina do zina: o (fan)zinski kulturi na Slovenskem. Master's thesis. University of Ljubljana, 2016, pp. 8-9. 9 GRIMES, Matt. From Protest to Resistance. In DINES, Mike - WORLEY, Matthew (eds.) The Aesthetic of Our Anger; Anarcho-Punk, Politics and Music. Colchester : Minor Compositions, 2016, pp. 161-162.

10 HEBDIGE, Dick. Subkultura a Styl. Praha : Volvox Globator, 2012, pp. 25-26; compare with MUGGLETON, David. Inside Subculture: The Postmodern Meaning of Style. Oxford : Berg Publishers, 2000, pp. 11-14.

11 MUGGLETON 2000, pp. 42-43.

12 STRAW, Will. Communities and Scenes in Popular Music. In GELDER, Ken (ed.) The Subcultures Reader. London : Routledge, 2005, pp. 469; compare with CÍSAŘ, Ondřej - KOUBEK, Martin. Include 'em All?: Culture, Politics and a Local Hardcore/punk Scene in the Czech Republic. In Poetics: Journal of Empirical Research on Literature, the Media and the Arts, 2012, Vol. 40, No. 1, pp. 4-8.

13 HAUNSS, Sebastian - LEACH, Darcy K. Scenes and Social Movements. In The Changing Structure of Civil Society, Workshop Number 8, European Consortium for Political Research, Joint Sessions of Workshops. Uppsala, 2004, pp. 3-5. 
activist. This term can help define a scene's hierarchy, that is, the relationship between the creator of artwork, who possesses greater subcultural capital, and the recipient or listener. ${ }^{14}$ Similarly, in this context the concept of "authenticity" is understood as a dividing point from the mainstream. ${ }^{15}$ Subcultural capital in this sense can also form an "alternative hierarchy" of a certain society; moreover, know-how for the production itself could be regarded as highly valuable subcultural capital. In this context, the punk notion of DIY is transformed into the idea that "anyone can do it"; that is, anyone can be a punk musician, a fanzine publisher or a record label operator, ${ }^{16}$ but according to the same logic, when there is a consented appeal that members of the scene should be active, then passivity is regarded as lazy consumerism and is thus denounced.

The contemporary hipster post-subculture rests partly on this subcultural capital logic. Hipsters oscillate between various independent scenes; as "artistic bohemians" they universally consume any type of independent ("indie") ${ }^{17}$ products. This phenomenon is based on a bricolage of many older subcultural styles. Within the fanzine scene, hipsters are a significant driving force behind the popularity of artzines, which are on the one hand the legacy of old countercultural publications and on the other a medium that expresses the "elitism" of hipness and "more refined taste." Contemporary zine fairs, where zine-makers meet, heavily revolve around artzine scenes and therefore rarely attract more straightforward, anti-elitist hardcore punks. Hipster-like behaviour within subcultures can have a counterpart in post-autonomous activists, who are pointedly described by social anthropologist Bob Kuřík: "Whereas the typical autonomist is a militant brat from a squat who listens to hardcore and punk, the typical post-autonomist is at first sight indistinguishable from a young student. He wears colourful clothes and listens to electronica. Whereas the autonomist tries to refuse all the old in himself and all around him, the post-autonomist tries to influence his background in new, social-ecological middle class." ${ }^{\prime 18}$

One way or another, how can certain political activities be supported by a cultural activity, specifically by fanzine publishing? Fanzines are often directly involved in organising political demonstrations and benefits concerts, and they report about such events on their pages afterwards. Zinesters can also support particular protests by reprinting the political argumentation, by publishing interviews with activists or by publishing images supporting or denouncing specific campaigns. Many fanzines contain columns that are broadly focused on politics. Interviews

14 THORTON, Sarah. The Social Logic of Subcultural Capital. In GELDER Ken - THORNTON, Sarah (eds.) The Subcultures Reader. London : Routledge, 1997, p. 191.

15 HUQ, Rupa. Resistance or Incorporation? Youth Policy Making and Hip Hop Culture. In HODKINSON, Paul - DEICKE, Wolfgang (eds.) Youth Cultures: Scenes, Subcultures and Tribes. London : Routledge, 2007, p. 80.

16 DALE, Pete. Anyone Can Do It: Empowerment, Tradition and the Punk Underground. London : Routledge, 2012, p. 34.

17 ARSEL, Zeynep - THOMPSON, Craig J. Demythologizing Consumption Practices: How Consumers Protect Their Field-Dependent Identity Investments from Devaluing Marketplace Myths. In Journal of Consumer Research, 2011, Vol. 37, No. 5, p. 792.

18 RYCHETSKÝ, Lukáš. Přepínání tváří: Rozhovor s antropologem Bobem Kuř́íkem o nových strategiích protestních hnutí. In Alarm, 11. July 2015, https://a2larm.cz/2015/07/prepinani-tvari/ 
often concentrate on political opinions or participation in demonstrations. Scene reports are one of the most important components of fanzines. They appear as reports or travelogues describing the authors' meeting with punkers and scenes in other countries (such reports also increase the subcultural capital of the publisher), which are often linked to anarchist centres or squats. In a similar way political movements or activist cells publish band interviews or reviews of albums released by kindred bands in their publications. Although many fanzines present themselves as primarily music-focused, they generally contain political content as well, at the very least in terms of iconography, for example, by printing anti-racist graphic motifs.

\section{The Czech and Slovak Punk Scenes during Late State Socialism}

The birth of Czech and Slovak hardcore punk and its cultural catchment area can only barely be linked to a remarkable creative movement or any local musical innovation, as many punk scene veterans suggest. ${ }^{19}$ Although many punk bands were active in the socialist 1980s (e.g. Plexis, Visací Zámek, Znouzectnost, Do řady!, S.P.S., N.V.Ú. and Zóna A, as well as hardcore bands like Radegast, Šanov 1, Telex, Suicidal Commando, Skimmed, Kritická Situace, Zelení Kanibalové, Zeměžluč, Vzor 60 and S.R.K., and more experimental bands like Insania, Michael's Uncle, Masomlejn, Modrý Tanky and Už Jsme Doma), the scene did not have a major influence on society as a whole nor did it produce any noteworthy music.

As Czech social geographer Michaela Pixová argues, this subculture had to armour itself against permanent obstructions and repression, and spaces where live performances were allowed were more than limited..$^{20}$ Recording and distributing LPs and fanzines were very risky activities, and only a few individuals were willing to run any kind of independent distribution. ${ }^{21}$ Very few fanzines were released at the time, ${ }^{22}$ and many of those that were circulated were based on translations from Western publications (such as Attack zine).$^{23}$ The finest ones from this era were certainly Oslí uši and Sračka. They took a broadminded approach, informing readers about, among other things, the growing racist skinhead element in Czechoslovakia. ${ }^{24}$ Throughout the DIY approach was remarkably underlined by the publisher of Oslí uši, who kept money-free distribution in order to "not to allow anyone to buy them, so as not to own them". ${ }^{25}$

19 Interview with Šoty/Zeměžluč. In For the Punx, 2006, No. 2, p. 30.

20 PIXOVÁ, Michaela. Český Punk za oponou i před oponou. In KOLÁŘOVÁ, Marta (ed.) Revolta stylem: hudební subkultury mládeže v České republice. Praha : SLON, 2011, pp. 58-61; compare with KUŘíK, Bob. Život je politickej čin. In Nový Prostor, 2010, No. 349, http://www.novyprostor.cz/clanky/349/zivot-je-politickej-cin. 21 FUCHS, Filip. Kytary a řev aneb co bylo za zdí: Punk rock a hardcore v Československu před rokem1989. Brno : Self-published, 2002, pp. 260-263.

22 Oslí uši story pt. I. In Muzika Komunika, No.2, https://muzika-komunika.blogspot.com/2014/01/osli-usistory-pt-i.html; Interview with Štěpán Stejskal. In Porodem vpřed, 1993, No. 1, p. 1.

23 Kristova léta českého punku. 33 let průšvihů i výher tuzemského punk rocku. 33 let od prvního punkového koncertu v Praze. Praha : Popmuzeum, 2012, p. 28.

24 Oi! akce. In Sračka, 1989, No. 3/4, unpaginated.

25 Oslí uši story pt. I. 
As historian Ondřej Daniel remarks, often drawing heavily from key Czech punk chronicler and fanzine publisher Filip Fuchs, some Czech and Slovak punks in the 1980s spread racist ideas, for example, 77-style ${ }^{26}$ the punk band Zóna A ${ }^{27}$ Important for this study is that racist expressions were also used by bands regarded as hardcore, which goes into the deepest contradiction to the nature of hardcore. For example, the members of Šanov 1 spoke about being openly racist in an interview with the zine Sračka. ${ }^{28}$ It should be noted, however, that they renounced such views in the 1990s.

Most bands at that time, however, tended to be apolitical. ${ }^{29}$ One person interviewed by Miroslav Vaněk for his oral history project about rock musicians in socialist Czechoslovakia described his musical activities as being purely musically focused: "I didn't care about politics; I was interested in hard rock." ${ }^{30}$ Czechoslovakia got its first taste of punk thanks to the members of the alternative/new wave band called Extempore. ${ }^{31}$ One member, Mikolá? Chadima, who would later chronicle the Czech alternative scene (despite never being a punk), started his own DIY tape label called Fist Records. Although the regime took an equally repressive approach to the alternative/new wave scene, ${ }^{32}$ its members did not share the punks' "outsider" stance. Many were university students from the bigger cities, and they were often officially registered as musicians. Moreover, they had remarkable patronage by the officially permitted Jazz Section of the Czech Musicians' Union, which produced many influential music magazines, some of which were official or semi-official and some of which were purely samizdat (secretly self-published). ${ }^{33}$ The Jazz Section was later banned and its leaders put on trial in the last years of the socialist period. Many Czech alternative bands that undoubtedly influenced the punk movement (Garage, Zikkurat, Extempore, OZW, Máma Bubo, Dybbuk) were at least in part engaged in DIY practices. The all-female alternative/new wave band Dybbuk (or its modification Zuby Nehty) was very influential for the first feminist subcultural activists. The members of this band also faced deeply rooted sexism that came from fans as well as other male punk musicians. ${ }^{34}$

Many of above these bands accumulated remarkable subcultural capital, partly because of their half-official status. It was not rare for this "socialist" subcultural capital to be an advantage in commercial music business activities after the fall of state socialism. For example, some became members of the unions protecting the rights of copyright holders, the OSA in the Czech Republic and the SOZA

26 This term usually refers to a band that is heavily influenced by the first wave of punk in the 1970s.

27 DANIEL, Ondřej. Kánon a alibi: anticiganismus postsocialistických subkultur. In Slovo a smysl, 2013, Vol. 10 , No. 20, pp. 265-266.

28 FUCHS 2002, p. 122.

29 VANĚK, Miroslav. Byl to jenom Rock'n'Roll? Hudební alternativa v komunistickém Československu 1956 1989. Praha : Academia, 2010, pp. 295, 550-552; PIXOVÁ 2011, pp. 58-61.

30 VANĚK 2010, p. 292.

31 FUCHS 2002, p. 18.

32 Aféra Jazzové sekce pokračuje. In Západ. Časopis pro Čechy a Slováky, 1983, (October). https://www. ustrcr.cz/data/pdf/casopis_zapad/1983_5.pdf

33 Náš Př́iběh. In Jazzová Sekce, 2016, https://jazzova-sekce.cz/nas-pribeh/

34 ŘíMANOVÁ, Jana. Role žen v historii českého punku. Master's Thesis. Charles University in Prague, 2015, pp. $42-44$. 
in Slovakia. Not surprisingly, hardcore punks despise these unions because they are seen as a pressure group of the music industry and a source of potential costs against DIY scenes. ${ }^{35}$

\section{Czechoslovak and Czech Punk at the Heart of Transformation and Globalization}

The above-mentioned explicit contradictions to hardcore ideas (racism, commercialism) meant that the "true" hardcore punk scene as defined above and connected with political grassroots activism could not have started before the Velvet Revolution. Contemporary witnesses, in fact, claim that the scene had to begin practically from scratch, searching for inspiration mainly from Germany. ${ }^{36}$ Some older punk bands from the socialist period (e.g., Plexis) were regarded as problematic, but not necessarily due to racism. Hardcore punks often blamed them for allowing themselves to be incorporated into the mainstream, that is, when they signed to the first big music labels. In response to such tendencies, a compilation album titled Fuck Off Major Labels!!! was produced and proved to be a workable DIY model for releasing hardcore punk and related music in the future. ${ }^{37}$ The campaign against major labels occurred especially in Czechia. The Slovak scene underwent similar development, although German autonomism was not a major influence and there was no influential anarchist publication equivalent to the Czech A-kontra magazine (which is discussed below). ${ }^{38}$

Moreover, the formation of a strictly DIY scene went hand-in-hand with the intertwining of hardcore punks and newly emerging anti-authoritarian groups. This development inspired many former "apolitical" punks to take up activism. Punk chronicler Filip Fuchs described this boom with the following words: "the wild underground extreme of human rights and ecological activities, in fact not based on a more sophisticated philosophy". ${ }^{39}$ This definition reflects among other things the first protests and demonstrations. Moreover, the best-known Czech and Slovak hardcore punk zines were launched in this period or during the late 1990s: Hluboká Orba (the most influential and activist), Malárie, Different Life, Noise Master, Papagájův Hlasatel, Death Fist, Rudé Právo, Cabaret Voltaire and Epidemie. Many of their editorial teams doubled as activist cells. In Czechia A-kontra, a key anarchist journal, was launched; in its earliest days it was even distributed in official newspaper kiosks. This journal influenced both activists and hardcore punks, who were often inspired to write polemical articles in their zines to challenge the "intellectual" A-kontra. ${ }^{40}$

Nevertheless, as the book Anarchistická publicistika 1990 - 2013 (Anarchist journalism, 1990 - 2013), published by the Czech and Slovak Anarchist Federation

35 Vitajte! In Archipelag Vinyl, http://www.avinyl.sk/

36 CÍSA

37 ŠTĚPÁNEK, Ondřej. Nedáme se pro peníze?! Komodifikace punku a rezistence proti ní. In DANIEL, Ondřej a kol. Kultura svépomocí. Ekonomické a politické rozměry v českém subkulturním prostředí pozdního státního socialismu a postsocialismu. Praha : Univerzita Karlova, 2017, pp. 130-131, 140-141.

38 H.A.D. Bratislavský scene report. In Smola, 1999, No. 1.

39 FUCHS 2013.

40 Blizard. Sexismus a Potraty. In Brněnská Vrtule, 1992, No. 4, p. 33. 
(ČSAF), suggests, beginning in approximately the mid-1990s protest movements aimed to move away from close subcultural links. ${ }^{41}$ At the height of anti-globalisation protests (around 1998 - 2002), punks were increasingly labelled as unwelcomed rioters. ${ }^{42}$ The Internet deepened the abyss between the activist sphere and hardcore punk scene and caused many zines to fold. But in the early 2000s a new generation of zinesters started to create, and titles such as Move Your Ass, Revoltär and Choroba mysli, appeared. Later in the decade titles like Smrt, Drunk Nach Osten, Kazimír, Chyba and Cerelitida were established. Current DIY hardcore-oriented publications - for example, Revenge of the Nerds, Disfrosten, Vyderrač, and Herbivore - also generally cover politics. Moreover, titles flirting with the artzine format can be found on the contemporary Czech hardcore punk scene as well, for example, the hardcore/feminist zine Mazinerie, the noise music zine Black Block Dog or the skatecore publication Crook.

Although new collectives are still popping up, the know-how and subcultural capital necessary for organising influential gigs and releasing records are seemingly still possessed by "the known few", for example, people associated with the Prague venue 007 or the band Kovadlina. ${ }^{43}$ Contemporary hardcore punks in Czechia and Slovakia comprise a self-contained scene. For some activist groups, such as the No to Racism! (Ne rasisimu!) initiative, the hardcore scene's anti-authoritarian potential seems to be no longer necessary.

The question of gaining subcultural capital and turning it into economical capital, especially in the context of hipsters, can perhaps be read between the lines, but exact data (at least with this fanzine-centred approach) for more precise research are not yet available. Some hardcore punk publishers avoid participating in the above-mentioned zine fairs and expos, ${ }^{44}$ whereas others have started creating publications in an artzine-like style (e.g., the contemporary Mazinerie zine). After the 2016 Prague Zine Fair, held at the Prague Trade Fair Palace, ${ }^{45}$ such a posh place so far away from DIY approach, the DIY Zine Fest, which was of hardcore persuasion, emerged in Moravia. One of its organisers, Monty, the publisher of fanzine Elens, describes the transformation of the scene from widespread "underground extreme" into a closed community of "collectors": "At Elens zine we try to put together material that is attractive to us and interests us personally, and it is possible that it may interest someone else, because the community of fanzine fans is as big as the community of tin-soldier collectors, so we cannot speak about some kind of revolutionary perspective. Fanzines were in my opinion always connected with punk. And the punk community is underground, a small one, just for enthusiasts and fanatics..." 46

41 Anarchistická publicistika 1990 - 2013. Praha : Nakladatelství Československé anarchistické federace, 2014, pp. 3-4; compare with CHARVÁT, Jan. Současný politický extremismus a radikalismus. Praha : Portál, 2007, p. 164.

42 A-kontra, 2000, No.7; Komunikace, 2001 (issue number unknown).

43 Compare with KUMOVÁ, Petra. DO IT YOURSELF TOGETHER. In CHARVÁT, Jan - KUŘÍK, Bob (eds.) Mikrofon je naše bomba: Politika a hudební subkultury mládeže. Praha : Togga, 2018, pp. 111-161.

44 MARTIN. Report z Prague Zine Festu 2015. In Cerelitida, 2015, No. 5.

45 KĽIVÁK, Prague Zine Fest 2016. In Crook, 24. April 2016, http://crook.cz/2016/04/prague-zinefest-2016/

46 Mapa zinové tvorby. Zinefest Brno. Brno, 2017, pp. 18-19. 


\section{Slovenia - The Avant-Garde Years in Declining Yugoslavia}

In Slovenia, which was part of the socialist country (Yugoslavia) that was arguably closest to the West, punk started almost as early as in the West. ${ }^{47}$ Padraic Kenney, a researcher specialised in studying protest movements in Central Eastern Europe during the twilight of the socialist era, regards Slovenia an avant-garde within the former Eastern Bloc. ${ }^{48}$ The regime's approach was regarded as monoclinous. The state's benevolence was, from time to time, replaced with arbitrary, brutal repression, police violence and close monitoring. Gregor Tomc, applying Herbert Marcuse's theory, calls this stance "repressive tolerance". 49

The primarily repressive approach to the punk scene in the late 1970s was symbolised by the "Nazi punk affair," when the official regime newspaper Nedeljski Dnevnik labelled punkers as "Nazis" conspiring to establish a "Fourth Reich."50 Such machinations continued for years, and many bands had difficulty finding a place to perform, especially in smaller towns. ${ }^{51}$ The ignorance and primitiveness that the authorities displayed discredited the regime in the eyes of contemporary youth and provided fertile ground for parody. The Slovenian "Nazi punk affair" had a Czechoslovak counterpart in the slanderous article "Nová vlna se starým obsahem" ("New wave with old contents"), which was published in the Czech official newspaper Tribuna. ${ }^{52}$ But in Czechoslovakia the result had a far smaller cultural response.

In the early 1980s a new wave of independent music culture challenged the late socialist Yugoslav state, which at that point was already unable to stop it. As I will demonstrate, fanzines played a remarkable role here. Besides Laibach, the most well-known band from this period, there was Borghesia, O!Kult, CZD, Otroci Socializma, Via Ofenziva, Kolaps, Odpadki Civilizacije, Phantasmagoria and Satan Panonski. ${ }^{53}$ Some of these groups were even permitted to release albums on the official Jugotron label. ${ }^{54}$ Censorship, however, did exist; for example, Pankrti

47 SODNIK, Melita. Ohranjeni Škucevi Fanzini, Zgodovinski kontekst in intermedialne navezave. Master's thesis, University of Ljubljana, 2013, p. 6.

48 KENNEY, Padraic. Karnevalem Revoluce. Praha : BB art 2005, pp. 255-258.

49 The state's repressive tolerance was the product of tolerance on both the part of citizens and the government: the tolerance on one hand from citizens who tolerated the government to represent the citizens tolerating the government, on the other the government allowing certain kinds of opposition that did not cross the borders of the status quo. Subcultures as well as the minorities, however, often went outside the status quo and hence repression was often aimed against them. TOMC, Gregor. A Tale of Two Subcultures: A Comparative Analysis of Hippie and Punk Subcultures in Slovenia. In LUTHAR, Breda - PUŠNIK, Maruša (eds.) Remembering Utopia: The Culture of Everyday Life in Socialist Yugoslavia. Washington : New Academia Publishing, 2010, p. 192.

50 LYDIA. Who Gives a Shit. In Maximumrocknroll, 2014, No. 378.

51 Interview with Šund. In Maximumrocknroll, 2014, No. 378.

52 Aféra Jazzové sekce pokračuje 1983.

53 Besides his extreme onstage behaviour (which involved violence and self-mutilation; he was nicknamed the "GG Allin of the Balkans"), he also declared a "punk revolution" throughout Yugoslavia, which would result in the creation of an independent punk community or even a state. GITTLITZ. A Biography of Satan. In KAMIKAZA, Satan Panonski fanzine, 30 March 2016,

https://satanpanonski.wordpress.com/2016/03/30/hard-blood-shock-a-biography-of-satan-panonski/

54 DUGONJIĆ, Siniša. Fanzini sa Marsa. Dokumentarac o srpskoj fanzinaškoj sceni osamdesetih i devedesetih godina. Satibara Film, 2011, https://vimeo.com/26816160 
agreed to change some lyrics on their album Dolgacajt (Boredom). ${ }^{55}$ The situation was practically incomparable to Czechoslovakia, where only two bands were given such an opportunity (Visací Zámek and Zóna A, both of which refused to change their lyrics). ${ }^{56}$

The most popular fanzine from that period was Bla bla bla, whose inaugural issue came out in the same year as the first issue of the legendary American hardcore zine Maximumrocknroll (1982). ${ }^{57}$ A series of influential zines followed, including Pankzija, Lolipop (later Benjamin), Inkriminalni produkt, Viks and Vrnitev odpisanih. The lion's share of zines produced at this time were strongly influenced by bands, especially Laibach and Borghesia, who printed them intentionally as manifests. This burst of zine activities would have been hardly possible without the support of Mladina magazine and the ŠKUC gallery, which printed and distributed fanzines and operated as a mediator between the authors and the censors. ${ }^{58}$ The courtyard of the ŠKUC gallery hosted punk gigs, while the neighbours often protested and security forces took an erratic approach..$^{59}$ Between 1981 and 1986, thanks to ŠKUC's involvement, 6,502 units of fanzines were printed. ${ }^{60}$ This number is indeed remarkable, keeping in mind that the regime was still repressive and the Socialist Republic of Slovenia was one of the smaller constituent states of the Socialist Federal Yugoslav Republic.

Many of the above-mentioned bands from the 1980s were not hardcore. Musically, they were closer to new wave (goth music and punk), but there were also some hardcore bands, such as the above-mentioned Odpadki Civilizacije or the all-female band Tožibabe. This group actively promoted hardcore and printed its own zines as well. ${ }^{61}$ Tožibabe's lyrics were introspective and critical, and thus the band was often visited by the secret police. ${ }^{62}$ Their Czech counterparts were easily Dybbuk, although this band was not as politically engaged.

In my interviews with Slovenian informants, I regularly asked them if they could think of any past racist elements in the Slovenian/Yugoslavian scene. No one could recall anything of the kind. On the contrary, as other sources point out, many Slovenian bands labelled themselves not only as typical punk "liberal anarchists" (see above), but even as leftist and socialist. Bojan, the singer from the band $\mathrm{Ku}-$ zle, is even more "leftist": "Yeah, we were against the system, but we were not thinking in a capitalist way. We were more to the left than that hypocritical system.

\footnotetext{
55 Interview with Pankrti. In Maximumrocknroll, 2014, No. 378.

56 ŠTĚPÁNEK 2017, p. 132.

57 SODNIK 2013, p. 15.

58 KENNEY 2005, p. 226; SODNIK 2013, pp. 10, 13.

59 Interview with Barbara Boršič. Ljubljana, November 2016.

60 SODNIK 2013, pp. 8-9.

61 Interview with Tožibabe. In Maximumrocknroll, 2014, No. 378.

62 SMITH, Geoff. Freezing within the Cold War, or Punk Within the Socialist States - Part 1. In Maximumrocknroll, 2014, No. 378.
} 
You can say that we were the Leninists of anarchists." ${ }^{13}$ In comparison, there were no truly leftist bands in the Czechoslovak scene, although some did shift to the left decades later (e.g., the above-mentioned Mikoláš Chadima). ${ }^{64}$

Coming back to fanzines, the first issue of Bla Bla Bla opened with a daring editorial that presented a manifesto; it proclaimed that rock music, especially punk, helps young people find themselves and that music should be revolutionary. ${ }^{65}$ How literally readers should have taken this statement is not important now, but we should not overlook the articulation of the link between music and lifestyle. Padraic Kenney and Slovenian media studies researcher Melita Sodnik regard such proclamations as pointedly activist in nature, thus challenging the official discourse. ${ }^{66}$ In every way, young Slovenian fanzine creators took shape especially in ambiguity and irony together with almost permanent parodying of late state socialist discourse, ${ }^{67}$ and hard erotica and pornography in general were the main semiotic weapons. Although this is not a surprising approach within the punk community, the Slovenian approach is quite an original intersection between the Western fetish/queer style and typical punk provocation (which was strongly used in Czechoslovakia right after the revolution).

Domen Repnik claims that Slovenian zinesters were even able to write about questions associated with capitalism and hence could have served as a platform for addressing issues that were underdiscussed at that time but which would soon become very important once the socialist regime fell. ${ }^{68}$ Although the hardcore style itself was not much disputed at that time, many bands from the 1980 s were not far from hardcore in terms of ideas, fanzine production and even activism.

\section{Slovenia: The Rise and Fall of the Hardcore Punk Scene}

Considering this legacy, it is a bit surprising that the new hardcore scene that emerged in the first decade after the fall of socialism (represented by bands such as Pizda Materna, Extreme Smoke 57, C.O.R., Aktivna Propaganda, Noise Order, Wasserdicht, Odpisani, Pridigarji, ${ }^{69}$ Totalna Revolucija and Man In The Shadow as probably the most influential Slovenian hardcore group) distanced itself from the previous decade's scene. Although there was no need to reckon with racism or nihilism, the new bands clearly distinguished themselves from the older groups, which were regarded as "99\% commercialised" ${ }^{70}$ The Abolishing Borders From Below bulletin, which was focused on anarchist scenes in South-Eastern and Eastern

63 Interview with Kuzle. In Maximumrocknroll, 2014, No. 378.

64 CHADIMA, Mikoláš. Všichni lidé jsou si rovni, ale někteř́i jsou si rovnější. In Deník Referendum, 15. February 2012, http://denikreferendum.cz/clanek/12561-vsichni-lide-jsou-si-rovni-ale-nekteri-jsou-si-rovnejsi

65 Bla Bla Bla, 1982, No. 1, unpaginated.

66 SODNIK 2013, p. 17.

67 Napotki za boljše življenje. In Bla Bla Bla, 1982, No. 2.

68 Interview with Domen Repnik, Ljubljana, November 2016.

69 The Scene in Slovenia. In Mankind Disaster, No. 2-3 / V.I.T.R.I.O.L., No. 5 (splitzine), 1997, unpaginated.

70 GALIČIČ, Matjaž. Komercialni underground - ne hvala! In V.I.T.R.I.O.L., 1996, No. 3. 
Europe, affirmed this tendency. It did not consider 1980s Slovenian punk to be ideologically allied. ${ }^{71}$ References to the older bands were also very limited on the pages of newly released zines.

The above-mentioned determining approach is especially visible in the critical article "Komercialni underground - ne hvala!" ("Commercial underground - no thanks!"), published in the fanzine V.I.T.R.I.O.L., which had a circulation of about 300 copies. Three hundred units of one zine issue indicate at least extraordinary interest within the subcultural field in such a small country. The article itself can be interpreted as a strong appeal to members of the scene, as it emphasises the distinction between what is and what is not DIY and thus what should be excluded from the scene. Although the timing and context are a bit different, there are some similarities between this article and the Czech Fuck Off Major Labels!!! campaign.

Even though the new scene distanced itself from the past, the strength of the subcultural activity seemingly persisted. New zines emerged within the newly formed scene, including 13.brat, Punktur, Platfuzz, Active Phase, Provokatorja, Cicifuj, Dickhead, Mankind Desaster, Entmoot, Picajzl, the above-mentioned V.I.T.R.I.O.L., Krull and Drunk in Public. Although I am not analysing political zines here, I should also mention the Slovenian anarchist zines Preporod and Lesbo zine and the Croatian Communitas. Famous 1980s artzines were in some way the antecedents of 1990 s comic titles. Comics were often included in punk fanzines as well. They were sometimes erotic or pornographic in nature, and their publishers often regarded themselves as anarchist sympathisers. ${ }^{72}$ In 1992 the comic zine Stripburger was launched and today is the most well-known Slovenian artzine $^{73}$ and perhaps the most well-known Slovenian zine of all time. It started out as a strictly DIY title with a critical approach; it has been based at the Metelkova squat (see below) in Ljubljana since it was founded. The zine crew was also involved in hardcore shows, and its main goal was to unite artists from all of the former Yugoslavia's successor states. Stripburger would eventually receive financial support from municipal authorities. The crew justified this as a "struggle for better conditions for the artists". ${ }^{74}$

The most well-known Slovenian hardcore fanzine, the above-mentioned 13.brat, contributed to the local scene's development. It was closely associated with the eponymous venue in Nova Gorica. The fanzine itself was influenced not only by the typical hardcore political agenda, but also by the legacy of 1980s pornographic-provocative content. Nevertheless, 13.brat was balanced in regards to the gender question as well, and pro-queer erotica was also used. But this particular zine is especially interesting because it possessed extraordinary subcultural capital; it was highly respected within DIY scenes despite the fact that some issues (but not all) were supported by the Open Society Foundation.

71 Young anarcho punk movement in Slovenia report. In Abolishing Borders from Below, 2002, No. 2, unpaginated.

72 Interview with Jure Perpar. In Kratki Stik, c. 1997, No. 2.

73 KOLMANČIC 2001 , pp. 61-62.

74 Interview with Katerina Mirović. Ljubljana, September 2015. 
Typical hardcore punk fanzines addressing political topics (for example, repression against anarchists, campaigns against supermarkets) were produced in both Slovenia and Czechia. Some titles took comparable approaches. For example, the above-mentioned Cicifuj and the Czech Underground Harmony both focused on the struggle to unite the entire underground, and the Slovenian Entmoot and the Czech Cabaret Voltaire both served as direct instruments of political campaigns. Although a comparison can be drawn between Hluboká Orba and 13.brat, the financial support that the Slovenian title received precludes it.

The DIY cultural activism of 1990s Slovenia was tightly linked to the Metelkova squat, which would later become a popular tourism site in Ljubljana. The squat's history stretches back to the Slovenian Spring protests of 1988, when the buildings served as military barracks. When Yugoslav troops finally evacuated the barracks (in 1991), the future of the complex was debated. Although city hall favoured the idea of demolishing the site, the antimilitaristic discourse of "culture space instead of military"75 inspired the Network for the Metelkova group to develop the Project Metelkova, a platform that united various activists and independent artists. Some members took direct action, occupying the barracks. Punks are remembered as the most tenacious defenders of Metelkova. ${ }^{76}$ Regardless of the successful occupation of the complex, part of the collective supported the idea of negotiating with the authorities and favoured the widespread renovation of the buildings to create a broader centre for contemporary art. For many years, there was a remarkable symbiosis here between subcultural youth, radical activists and artists. ${ }^{77}$

After the successful defence of the complex from destruction, its buildings were transformed into venues and galleries filled with various DIY art exhibits. DIY zines and newsletters were printed there as well. The first to be issued was Emzin (or MZIN) ${ }^{78}$ which was followed by Muha and later Metelkovnik. The KUD Mreža artist collective took the line of negotiation and has maintained it up to the present. ${ }^{79}$

The punks squatting at Metelkova were unruly nihilists fuelled by drugs who ended up burning the Šola building to the ground in 1994. After this incident, the punk influence at Metelkova nearly disappeared. ${ }^{80}$ The activist-subculture split occurred in Slovenia earlier than the peak of anti-globalisation protests. Nonetheless, punk concerts and even festivals were still held there, mostly in the Gromka building, organised by the Rafal Crew. This promotion team possesses significant subcultural capital and supports only a selected circle of bands, and so not just anyone can play there. ${ }^{81}$

In comparison, Czech squats, such as Ladronka (evicted in 2000) or Milada (evicted in 2009), were also remarkably important for local autonomist movement as well as for culture in general, but, as Czech social anthropologist Arnošt Novák claims,

75 ŽAGAR, Janina. Metelkova (Město). Master's thesis, University of Ljubljana, 2006, pp. 25-27.

76 Young anarcho punk movement in Slovenia report, 2002.

77 BEJŠOVEK 2015, p. 9.

78 Metelkovnik, 1998, No. 1, p. 12.

79 About KUD Mreža. In Kudmreza.org, http://kudmreza.org/about-kud-mreza/

80 Interview with Goran Medjugorac. Ljubljana, November 2016.

81 BABIČ, Jasna. V vrtincu subkultur. Ljubljana : Sophia Publisher, 2016, pp. 84-85; Interview with Jasna Babič. Ljubljana, September 2015. 
they were still limited to subcultural life. ${ }^{82}$ The only Czech squat that transgressed the subcultural level, the more recent Prague-based Klinika, was shut down as well. Despite its slightly different focus, it still met the same fate.

After the turn of the new millennium, the hardcore scene declines significantly in Slovenia, and practically all the fanzines disappeared. Because these publications are the most important sources for the history of the scene, the resulting gap means we cannot really determine what happened. In 2000 Marko Rusjan of Man in the Shadow described the scene as weak and small, noting that zinesters would publish two or three issues of a zine before giving up. ${ }^{83}$ As he later remarked in his book, a small scene means that its members tend to stick close together, but when one person leaves, for whatever reason, the scene can easily fall apart before vanishing entirely. When the scene is bigger, Rusjan remarked, as it was in larger countries and cities, people can come and go without having an effect on the scene's core. ${ }^{84}$

Of the contemporary Slovenian DIY publications only the satirical Mizantrop (influenced by the erotic and provocatively raw new-wave style of the 1980s) and the obscure $P A F$ can be considered punk influenced. In an interview, Biga, the publisher of $P A F$ and speaker of Radio Študent, emphasised the so-called generation gap between contemporary zinesters and publishers from the past who have ceased producing zines. ${ }^{85}$ Jasna Babič - subcultural researcher, Gromka producer and Rafal Crew co-leader - explained to me that the contemporary Slovenian punk scene is simply lacking "kids" (i.e., people younger than twenty). ${ }^{86}$ Domen Repnik also noted the difficult conditions for local promoters - every public event with more than one hundred attendees must be reported to city hall, security must be provided and tax on the entrance fee must be paid. ${ }^{87}$ But without any support or distribution, the key place where the cultural products can be spread is a DIY concert.

Despite the above-described situation, not all zine production has disappeared. Today, artzines dominate in Slovenia. The creators of these publications usually put individualism before any scene. Moreover, artzinesters generally do not shy away from institutional support, as they often use every possible asset or any help that cultural institutions offer. ${ }^{88}$ Nonetheless, this milieu has not wholly given up on the DIY idea. Many artzinesters are politically engaged, although they tend to subscribe to post-autonomism. They are often vegan or straight edge and thus follow lifestyles that used to be bound to the hardcore punk scene. ${ }^{89}$

82 NOVÁK, Arnošt. Obsat' a žij: squatting a politika každodennosti v Praze. In CHARVÁT, Jan - KUŘíK, Bob (eds.) Mikrofon je naše bomba: Politika a hudební subkultury mládeže. Praha : Togga, 2018, pp. 259-263.

83 Interview with Man in the Shadow, 2000, p. 26.

84 Miran Rusjan interview. In RUSJAN, Marko. Strah před svobodo, hardkor in upor. Nova Gorica, 2014, pp. 125126.

85 Interview with Nejc Bahor. Ljubljana, November 2015.

86 Interview with Jasna Babič. November 2015.

87 Ministrstvo za notranje zadeve. Javni Shodi in Javne Prireditve, http://www.mnz.gov.si/si/mnz_za_vas/ drustva_ustanove_shodi_prireditve/javni_shodi_in_javne_prireditve/; compare with Ministrstvo za javno upravo, Prijava javne prireditve oz. Shoda, https://e-uprava.gov.si/podrocja/vloge/vloga.html?id=1327.

88 Interview with Barbara Beškovnik, November 2016.

89 For example, Look Back and Laugh crew, which organizes the Caffeine Hours zine fair in Ljubljana. Interview with Domen Repnik, Ljubljana, November 2016. 


\section{Conclusion}

In Czechoslovakia, the state socialist regime limited the creative activities of punks. Political engagement and the emergence of a "true" hardcore punk scene came only after the Velvet Revolution. This scene offered a wide connection with activism that lasted for almost an entire decade and sowed the seeds for the establishment of many non-profit organisations, especially environmental ones. It also condemned the racism that was still present among some older punk bands and individuals. In contrast to Czechoslovakia, the Slovenian scene and its fanzines seemed to be far more belligerent towards the weak but nonetheless still repressive regime. The scene went beyond just punk rebellion, and its influence on the whole society is confirmed by many sources. Finally, it did so without containing flagrantly racist elements, which are contradictory to the tenants of hardcore punk. As one columnist from Maximumrocknroll concludes, this scene showed the real strength of punk, which at that time "exceeded just the level of symbolic threat."

After the fall of socialism, hardcore punk scenes emerged in Czechia and Slovenia and quickly became part of an international community. Although they were strongly connected to anti-authoritarian activism, in both cases scene members carefully distinguished the current scene from the past scenes. In the case of clarification and later the maintenance of hardcore-punk, anti-chauvinistic approaches, fanzines had a key role in all mentioned countries. Titles such as Hluboká Orba (or Nauzea from Slovakia) and 13. brat look quite similar, if we compare them in retrospect. But Hluboká Orba, personified by its publisher Filip Fuchs, remained strictly DIY and never accepted any institutional help, even though the political activities associated with it were bound to non-profit organisations. In contrast, 13.brat was willing to take advantage of official help. This may have influenced the approach of contemporary artzines, whose publishers openly use institutional sources and funds.

In one issue of the Mizantrop zine, one of the few non-artzine titles published in Slovenia after the turn of the new millennium, the editor noted, fittingly for this study, that Slovenian zinesters were writing only for a limited group of people that is getting smaller and smaller. ${ }^{91}$ The Internet changed the zine community entirely. In the Czech Republic and Slovakia, however, the hardcore punk scene seemingly overcame this crisis, and today fanzines are becoming more popular, even though the zine community remains quite closed.

Whereas in the Czech Republic and especially in Slovakia squatting has been permanently repressed, with essentially zero-tolerance policies in place after the new millennium, in Slovenia the squatting scene has thrived. In contrast, it is very hard to organise pub concerts in Slovenia, whereas in the Czech Republic practically anyone can do it. This may be the reason why there is no notable generation gap and a steady stream of "kids" coming into the scene in Czechia. In contrast, due to the Slovenian generation gap, it is hardly surprising that zines have disappeared.

90 LYDIA 2014.

91 Mizantrop, 2008, No. 1, p. 10. 
On the other hand, a strong squat scene has persisted in Ljubljana, but we can presume that the strict repression is no longer needed due to gentrification and elitism of the cultural milieu, which in fact goes hand in hand with individualistic capitalism. Having subcultural capital is anyway necessary for an efficient combination of subcultural and activist life in Slovenia as well as in Czech Republic (some pure DIY subcultural/activist groups still operate, but their influence within the scene is minimal). DIY ethics as defined by George McKay and also as a hardcore-punk legacy nevertheless remain current; they have been used during the struggle against gentrification as well as when the new grassroots activist cells have been founded.

\section{Cituj:}

Almer, Jiři. "The wild underground extreme of human rights and ecological activities": Czechoslovak, Czech and Slovenian hardcore punk fanzine cultures from the 1980s to the Present. In Forum Historiae, 2020, Vol. 14, No. 1, s. 68-83. ISSN 1337-6861. DOI: https://doi.org/10.31577/forhist.2020.14.1.6

Mgr. Jiří Almer

Ústav českých dějin

Filozofická fakulta Univerzity Karlovy

Náměstí J. Palacha 2

11638 Praha 1, Česká republika

E-mail: jirimaiden@seznam.cz 